UDK 008:351.853(438)

DOI: $10.5937 / \mathrm{RKSPP} 2102061 \mathrm{~L}$

ANDRZEJ JAKUBOWSKI

\title{
THE CONCEPT OF NATIONAL TREASURES UNDER POLISH AND EU CULTURAL HERITAGE LAW
}

"National treasure" is one of the key notions of cultural heritage law. It is of particular relevance for the European Union in the context of the free movement of goods in the Single Market and the permitted exceptions to this freedom. In principle, it refers to those objects "possessing artistic, historic or archaeological value" whose preservation is in the vital cultural interest of the Member State concerned. Hence national law constraints on their import and export do not violate treaty obligations in force so long as such constraints are not arbitrary or do not constitute disguised restrictions on trade between Member States. The question arises, however, as to the practical meaning of this notion, i.e. whether Member States can freely determine what constitutes a "national treasure". This article seeks to answer that question by analysing how the notion of national treasures was transposed into the Polish legal system in 2017, and what the consequences of this recent regulatory intervention might be. Poland

Key words: art trade, cultural exception, cultural heritage, European Union,

Dr. Andrzej Jakubowski is affiliated with the UNESCO Chair in Cultural Property Law at the University of Opole, Poland, where he leads the project "Legal forms of cultural heritage governance in Europe - a comparative law perspective", No. UMO-2019/35/B/HS5/02084, funded by Poland's National Science Centre, e-mail: andrzej.jakubowski@uni.opole.pl. The author wishes to acknowledge that the research for the present article has been undertaken within the framework of this project. 


\section{N T R O D U C T I O N}

The intersection between international commerce and cultural heritage protection is often framed in terms of an exception in international trade law for measures imposed to protect national treasures of artistic, historic or archaeological value. ${ }^{1}$ Most international free trade treaties provide exceptions to ensure the protection of such treasures. ${ }^{2}$ These exceptions can be found both in the law of the World Trade Organization (WTO) - under Article XX(f) of the General Agreement on Tariffs and Trade (GATT 1994) ${ }^{3}$ - and in other international economic agreements, in particular under Article 36 of the Treaty on the Functioning of the European Union (TFEU; ex Article 30 of the Treaty establishing the European Community). ${ }^{4}$ Pursuant to these exceptions, constraints on the import and export of national treasures are permitted and legitimate as long these are not arbitrary or do not constitute disguised restrictions on trade between European Union (EU) or WTO members. ${ }^{5}$ Hence the definition of what is protected is thus crucial for determining which goods can be freely (and lawfully) traded.

However, the actual definition of what such national cultural treasures are is no easy task. This is all the more so because both the legal literature and legislation often refer to different categories of cultural goods. ${ }^{6}$ Importantly, neither the WTO nor EU rules provide a definition of national cultural treasures, and under domestic law this category can comprise both movable and immovable objects, and sometimes intangible goods of exceptional importance for the cultural heritage of a state.

The problem is particularly relevant for the EU legal system, because the competence of Member States to choose their internal measures for protecting cultural heritage on the Single Market is supported by the mechanism regarding the return of those cultural objects which were unlawfully removed - that is exported in contravention

1 See Tania Voon, "National Treasures at the Intersection between Cultural Heritage and International Trade Law", The Oxford Handbook of International Cultural Heritage Law (Eds. Francesco Francioni, Ana Filipa Vrdoljak), Oxford, 2020, 507 ff.; Jia Min Cheng, "The Problem of National Treasure in International Law”, Oregon Review of International Law, Vol. 12, No. 1, Salem, 2010, $141 \mathrm{ff}$.

2 For a detailed overview, see Jingxia Shi, Free Trade and Cultural Diversity in International Law, Oxford-Portland, 2013.

3 General Agreement on Tariffs and Trade 1994, 15 April 1994, Marrakesh Agreement Establishing the World Trade Organization, Annex 1A, 1867 U.N.T.S. 187.

4 Consolidated version, OJ C 202, 7.06.2016, 47.

5 See Gabriele Gagliani, "Interpreting and Applying Article XX(f) of the GATT 1994: 'National Treasures' in International Trade Law', Santander Art and Culture Law Review, Vol. 5, No. 2, Opole, 2019, 48-49.

6 See T. Voon, op. cit., 508. 
of domestic protective measures - from the territory of a Member State. In such a context, the question arises as to the practical meaning of this notion, i.e. whether Member States can freely determine what constitutes a "national treasure".

This article seeks to answer that question by analysing how the notion of national treasures was transposed into the Polish legal system in 2017. First, it outlines the nature and scope of EU legal engagement in relation to the protection of national cultural treasures. Secondly, it explains how this notion has evolved since the Treaty of Maastricht until the present day, addressing the relevant provisions of the export regulation (Regulation No. 116/20097) and the two directives on the return of cultural objects (Directive 93/7/EEC; ${ }^{8}$ and Directive 2014/60/EU ${ }^{9}$ ). Thirdly, it analyses the relevant provisions of the Polish Act of 25 May 2017 on the Restitution of National Cultural Property (ARNCP). ${ }^{10}$ Finally, it provides an overview of the practical consequences of this recent regulatory intervention for legal certainty in the EU legal space.

\section{THE NOTION OF NATIONAL TREASURES UNDER EU LAW}

The beginnings of European integration within the three original Communities were aimed mainly at economic integration and closer political and economic cooperation between Member States. Cultural cooperation, and in particular the protection of Europe's cultural heritage, was long treated only as a side issue. As integration developed however, the scope of the common action broadened. ${ }^{11} \mathrm{To}-$ day, culture and the protection and enjoyment of cultural heritage constitute an important segment of EU action, touching upon its axiological and constitutional

7 Council Regulation (EC) No. 116/2009 of 18 December 2008 on the export of cultural goods, OJ L 39, 10.2.2009, 1. It replaced the earlier and several times amended Council Regulation (EEC) No. 3911/92 of 9 December 1992 on the export of cultural goods, OJ L 395, 31.12.1992, 1.

8 Council Directive 93/7/EEC of 15 March 1993 on the return of cultural objects unlawfully removed from the territory of a Member State, OJ L 74, 27.3.1993, 74-79.

9 Directive 2014/60/EU of the European Parliament and of the Council of 15 May 2014 on the return of cultural objects unlawfully removed from the territory of a Member State and amending Regulation (EU) No 1024/2012 (Recast), OJ L 159, 28.5.2014, 1-10.

10 Consolidated version, Polish Journal of Laws 2019, issue 1591.

11 For instance, see Rachael Craufurd Smith, "Europe", The Oxford Handbook of International Cultural Heritage Law (Eds. Francesco Francioni, Ana Filipa Vrdoljak), Oxford, 2020, 921-22; Cynthia Scott, "Conceptions of a Shared, Common, or European Heritage in the Emerging Heritage Diplomacy of the European Union, 1973-92", Cultural Heritage in the European Union. A Critical Inquiry into Law and Policy (Eds. Andrzej Jakubowski, Kristin Hausler, and Francesca Fiorentini), Boston-Leiden, 2019, 13ff.; Evangelia Psychogiopoulou, The Integration of Cultural Considerations in EU Law and Policies, Boston-Leidenm, 2008, 1-24. 
foundations. ${ }^{12}$ Yet at the same time EU competences are limited in this regard. Under Article 3(3) of the Treaty on the European Union (TEU), the Union shall respect the "rich cultural and linguistic diversity" of Europe and "ensure that Europe's cultural heritage is safeguarded and enhanced." 13 In relation to this, Article 6 TFEU defines the EU competences in the field of culture as supporting, coordinating or supplementing the actions of Member States, without thereby suspending their competence in this area, and without entailing the harmonization of Member States' cultural heritage law. Moreover, as determined by Article 167 TFEU, the Union "shall contribute to the flowering of the cultures of the Member States, while respecting their national and regional diversity and at the same time bringing the common cultural heritage to the fore". The EU has also consistently articulated, throughout the development of the European project, the significance of and need for protection of the national treasures of Member States. ${ }^{14}$

\section{National treasures and Article 36 TFEU}

Since the Treaty of Rome (1957), the protection of Member States' national heritage can serve as a rationale for restricting the freedoms of the internal market. It should be stressed that contrary to the expectations of some Member States, cultural goods are not excluded from intra-EU trade in goods. According to the Court of Justice of the European Union (CJEU), the fact that certain objects have historical or artistic value does not deprive them of the characteristics of goods. ${ }^{15}$ In other words, under EU law the circulation of cultural goods is unlimited, except as provided for in Article 36 TFEU. Hence a Member State may, in accordance with the principle of proportionality and without resorting to arbitrary discrimination, restrict the export of cultural goods from its territory. ${ }^{16}$

12 Andrzej Jakubowski, "Common Cultural Heritage, the European Union, and International Law", Cultural Heritage in the European Union. A Critical Inquiry into Law and Policy (Eds. Andrzej Jakubowski, Kristin Hausler, and Francesca Fiorentini), Leiden-Boston, 2019, 52-56.

13 Consolidated version, OJ C 202, 7.06.2016, 13.

14 See Michele Graziadei, Barbara Pasa, "The Single European Market and Cultural Heritage: The Protection of National Treasures in Europe", Cultural Heritage in the European Union. A Critical Inquiry into Law and Policy (Eds. Andrzej Jakubowski, Kristin Hausler, and Francesca Fiorentini), Boston-Leiden, 2019, 79ff.; Sabrina Ferrazzi, "EU National Treasures and the Quest for a Definition", Santander Art and Culture Law Review, No. 2, Vol. 5, Opole, 2019, 57ff.; Tania Kyriakou, "The Protection of National Treasures in the EU Single Market", Cultural Governance and the European Union (Ed. Evangelia Psychogiopoulou), London, 2015, 63ff.; Irini A. Stamatoudi, Cultural Property Law and Restitution: A Commentary to International Conventions and European Union Law, Cheltenham-Northampton, 2011, 112-32.

15 Commission of the European Communities v Italian Republic, Case 7-68 (Judgment of 10 December 1968) ECR 1968, 423.

16 See S. Ferrazzi, op. cit., 69. 
It is not however clear what exactly this means in practice, as both primary and secondary EU law offers no legal definition of such goods. The CJEU has not yet provided a definition either. It therefore seems very difficult, if not impossible, to develop a common definition of cultural objects for all Member States. ${ }^{17}$ Moreover, the actual wording of Article 36 TFEU in its various linguistic versions differs substantially. For instance, while the English or French versions use the term "national treasures" (trésors nationaux), the German and Polish versions use the term "national cultural property" (Kulturgut and narodowe dobro kultury, respectively), while the Italian and Spanish ones use the term "national heritage" (patrimonio nazionale, patrimonio nacional, respectively). ${ }^{18}$

The aforementioned terminological and linguistic differences demonstrate one of the key challenges of EU constitutional law in relation to the free movement of cultural goods. While the area of the free movement of goods falls within the EU's exclusive competence, the protection of national heritage and its integrity (including measures designed to protect cultural objects against illicit trade and removal from a state territory) lies within the competences of Member States. In other words, it is up to the Member States to define the content of the term "cultural objects of artistic, historical or archaeological value" within the framework of their internal legal systems. ${ }^{19}$ Yet, "this competence is neither exclusive nor unlimited", as it needs to be proportionate and serve the aim of the exceptions under Article 36 TFEU. ${ }^{20}$ So the question arises: Are there any more clear indications on how to interpret the meaning of "national treasures"?

\section{Export of cultural goods under EU law}

In response to the above question, certain guidelines can be found under EU law instruments adopted to meet the challenges of the Single Market. ${ }^{21}$ The first one regards the uniform regime for the export of cultural goods outside

17 Ibidem, 68-72.

18 See Manlio Frigo, "Cultural property v. cultural heritage: A 'battle of concepts' in international law?", International Review of the Red Cross, Vol. 86, No. 854, Cambridge, 2004, 371-72.

19 For instance, see Anna Frankiewicz-Bodynek, Piotr Stec, "Defining 'National Treasures' in the European Union. Is the Sky Really the Limit?", Santander Art and Culture Law Review, Vol. 5, No. 2, Opole, 2019, $135 \mathrm{ff}$.

20 See I.A. Stamatoudi, op. cit., 121-22; also see A. Frankiewicz-Bodynek, P. Stec, op. cit., 80-84.

21 See S. Ferrazzi, op. cit., 65-67; Andrea Biondi, “The Merchant, the Thief \& the Citizen: The Circulation of Works of Art Within the European Union”, Common Market Law Review, Vol. 34, No. 5, Leiden, 1997, 1173ff. 
the customs territory of the EU, set out in Regulation No. 116/2009. This instrument is designed to ensure that uniform controls are carried out on these exports at the EU's external borders, and thus it serves to assist Member States in their efforts to protect their national cultural heritage. In other words, it offers a general framework for protecting the integrity of the national heritages of EU Member States. The categories of cultural items to which the regulation applies are listed in its Annex I to Regulation No. 116/2009. These are based on the specific categories of objects and financial thresholds applicable to each category.

It is frequently posited that the content of Annex I can be seen as defining the notion of "national treasures" under EU law. However, while this particular definition for export purposes is useful for protective purposes as well, ${ }^{22}$ it cannot serve as a tool for interpretation of the meaning of "national treasures" under Article 36 TFEU. ${ }^{23}$ Indeed, Regulation No. 116/2009, under Considerandum no. 7, specifically states that Annex I is only "aimed at making clear the categories of cultural goods which should be given particular protection in trade with third countries, but is not intended to prejudice the definition, by Member States, of national treasures within the meaning of Article 30 [Article 36] of the Treaty". It also needs to be underlined that under Article 1 of Regulation No. 116/2009 the term "cultural goods" refers to the items listed in Annex I, "[w]ithout prejudice to Member States' powers under Article 30 [Article 36] of the Treaty."

\section{Directive 93/7/EEC}

Clearly, the meaning and practical operationalization of the notion of "national treasures" is of key importance for the intra-EU trade in cultural goods. In this regard, Article 1(1) of the former return directive, Directive 93/7/EEC, defined the term "cultural object", for the purposes of this instrument as an object "classified, before or after its unlawful removal from the territory of a Member State, among the 'national treasures possessing artistic, historic or archaeological value' under national legislation or administrative procedures within the meaning of Article 36 of the Treaty". However, it also required that such an object met one of two alternative prerequisites.

The first prerequisite regards objects belonging to the categories listed in the Annex to this directive (reflecting those enumerated in Annex I to Regulation No. 116/2009). Accordingly, "national treasures" within the meaning of Article 36

\footnotetext{
22 See I.A. Stamatoudi, op. cit., 120.

23 Ibidem, 135; S. Ferrazzi, op. cit., 67.
} 
TFEU must belong to one of these categories in order to qualify for return under Directive 93/7/EEC. The Annex also provided for financial thresholds applicable to certain categories of objects. The second, alternative prerequisite, concerns those objects forming "an integral part of public collections listed in the inventories of museums, archives or libraries' conservation collection". According to this provision, the category of "public collections" not only covered property defined as "public" under the legislation of a Member State, but also objects in "the inventories of ecclesiastical institutions".

In light of the above, it might seem that Directive 93/7/EEC offered a kind of interpretation of the notion of "national treasures" under EU law. However, the Preamble to this Directive explicitly stated that the Annex is not "intended to define objects which rank as 'national treasures' within the meaning" of Article 36 TFEU. Instead, it merely lists "categories of object which may be classified as such and may accordingly be covered by the return procedure introduced by this Directive".

\section{Directive 2014/60/EU}

The reform of the EU system for protecting the national treasures of Member States resulted in a new directive - Directive 2014/60/EU. This instrument adopted a solution that allows Member States to exercise competence over measures for protecting their national heritage, while recognizing the diversity of national arrangements, with no reference to additional categories of assets. Therefore, Directive 2014/60/EU does not feature a detailed annex that would require cultural objects to belong to specific categories or comply with thresholds related to their age and/or financial value in order to qualify for return. Pursuant to the Preamble to this instrument ( $9^{\text {th }}$ Recital), its scope "should be extended to any cultural object classified or defined by a Member State under national legislation or administrative procedures as a national treasure possessing artistic, historic or archaeological value within the meaning of Article 36 TFEU." Hence this EU law instrument is intended "to cover objects of historical, paleontological, ethnographic, numismatic interest or scientific value, whether or not they form part of public or other collections or are single items, and whether they originate from regular or clandestine excavations, provided that they are classified or defined as national treasures".

In this regard, under Article 2(1) of Directive 2014/60/EU the term "cultural object" concerns "an object which is classified or defined by a Member State, before or after its unlawful removal from the territory of that Member State, as being among the 'national treasures possessing artistic, historic or archaeological 
value' under national legislation or administrative procedures within the meaning of Article 36 TFEU". As was the case with the former directive, the new Directive 2014/60/EU defines "unlawful removal from the territory of a Member State" as that undertaken in breach of a Member State' rules on the protection of national treasures or in breach of Regulation No. 116/2009, or in contravention to the rules on lawful temporary removal (Article 2(2)).

It should also be emphasised that Directive 2014/60/EU also calls for cooperation in the creation of a legitimate art market and in the fight against illicit trafficking. ${ }^{24}$ In this context, it recalls the 2011 Council conclusions on preventing and combating crime against cultural goods. ${ }^{25}$ In that document the Council recommended that the Member States consider the ratification of the 1970 UNESCO Convention on the Means of Prohibiting and Preventing the Illicit Import, Export and Transfer of Ownership of Cultural Property, ${ }^{26}$ and the 1995 UNIDROIT Convention on Stolen or Illegally Exported Cultural Objects. ${ }^{27}$ It can thus be summarized that Directive 2014/60/EU creates the conditions in which Member States should work together to promote mutual respect for each other's cultural sensitivities and the diversity of their domestic systems for the protection of cultural heritage, as well as international law obligations in this regard. However, this common goal and trust should not be abused within the framework of the Single Market and the increasing cultural cooperation between Member States.

\section{THE POLISH ACT OF 25 MAY 2017 ON THE RESTITUTION OF NATIONAL CULTURAL PROPERTY (ARNCP)}

The implementation process of Directive 2014/60/EU has demonstrated that Member States indeed have adopted various strategies and various definitions of national treasures, ranging from very broad to more restrictive or "elitist" ones concerning only the most precious or important elements of tangible cultural heritage. ${ }^{28}$ The Polish case is perhaps one of the most interesting examples of a national implementation because of its approach to the meaning and scope of the term "national treasures."

24 Preamble, $16^{\text {th }}$ and $17^{\text {th }}$ Recitals.

25 Adopted on 13 and 14 December 2011, https://www.consilium.europa.eu/uedocs/cms_data/ docs/pressdata /en/jha/126866.pdf, 03.10.2021.

26 Adopted on 14 November 1970, entered into force 24 April 1972, 823 UNTS 231.

27 Adopted on 24 June 1995, entered into force on 1 July 1998, 2421 UNTS 457.

28 See Marie Cornu, "Recasting Restitution: Interactions between EU and International Law", Uniform Law Review, Vol. 20, No. 4, Rome, 2015, 643; M. Graziadei, B. Pasa, op. cit., 97-98. 


\section{The notion and scope of "national cultural property"}

As already mentioned, the term "national cultural property" (narodowe dobra kultury) is used in Article 36 of the Polish version of the TFEU. However, in Poland's domestic law, it long remained undefined. In the period 2003-2017 the national cultural heritage legislation did not even define the term "cultural property", although various legal provisions, including those of the Polish Constitution and those regarding Poland's international obligations in the field of cultural heritage protection, used the term in various contexts. Under the 2003 Polish Act on the Protection and Guardianship of Monuments (APGM) ${ }^{29}$ - the key legislative instrument in the heritage domain - the legally-protected category was a "monument", that is "immovable or movable property, parts or assemblages thereof, being the work of man or connected with his activity and representing a past epoch or event, the preservation of which is in the public interest because of its historical, artistic or scientific value" (Article 3(1)).

This did not change following Poland's accession to the EU and its associated obligation to transpose the provisions of Directive 93/7/EEC into national law. For the purpose of this directive the content of the Annex was transferred to Article 64 APGM and extended to monuments listed in the register of monuments (i.e. covered by the key form of legal protection); forming part of public collections that are the property of the Treasury, local authorities and other organisational units that are part of the public finance sector; contained in the inventories of museums or national library collections; or contained in church inventories. In this context, it is worth noting that the APGM included, since 2015, a special category of movable monuments inscribed on the Heritage Treasures List (Lista Skarbów Dziedzictwa). This category was considered to contain objects of utmost importance for the Polish cultural heritage, ${ }^{30}$ and was also included in the catalogue under Article 64 APGM.

In light of the above, it is important to underline that the notions of "cultural property" and "national cultural property" were defined only in the ARNCP, which transposed the provisions of Directive 2014/60/EU to the Polish legal system and repealed the APGM in this regard. According to Article 2(1) ARNCP "cultural property" means "monument" as defined under the APGM, and "a movable thing

${ }_{29}$ Polish Journal of Laws 2003, No. 162, issue 1568; consolidated version: Polish Journal of Laws 2021, issue 710 as amended.

30 See Piotr Stec, "The Lady or the Tiger? Legal Pitfalls of Implementing the Return of Cultural Goods Directive", Santander Art and Culture Law Review, Vol. 2, No. 2, Bydgoszcz, 2016, 142-45; also see M. Graziadei, B. Pasa, op. cit., 96-97. However, it should be noted that this form of protection of movable monuments has not been used in administrative practice. So far no proceedings for inscribing a monument on the List of Treasures of Heritage have been carried out, and the current legislative work provides for the abolition of this form of protection. 
that is not a monument, as well as their components or ensembles, the preservation of which is in the public interest because of their artistic, historical or scientific value, or because of their significance for heritage and cultural development."

In connection with the transposition of the provisions of Directive 2014/60/ EU, the ARNCP separately defines "national cultural property of the Republic of Poland" as well as "foreign national cultural property" within the meaning of Article 36 TFEU. As regards the first category, Article 2(4) of the ARNCP provides that this category includes: historical monuments whose permanent export abroad is subject to authorization; historical monuments whose permanent export is prohibited; archival materials forming part of the collections of national archives; library materials which are not historical monuments included in the collections of the national libraries; as well as objects which are not historical monuments provided that they are included in the inventory of museum objects of the state or local authorities. As regards the second category ("foreign national cultural property"), it refers to property classified or defined by a Member State of the EU other than Poland, on the basis of its legislation or administrative procedures, as a national cultural good of artistic, historical or archaeological value within the meaning of Article 36 TFEU. While the latter definition repeats the relevant provision of Directive 2014/60/EU (Article 2(1)), the former one extends to all cultural property that is not only prohibited from being permanently exported abroad, but also cultural property whose permanent export abroad is subject to authorization. In this way it covers a very wide spectrum of cultural property, encompassing de facto all objects possessing any significant artistic, historic or archaeological value. ${ }^{31}$

\section{The notion of "unlawful removal from the from the territory of Poland" and legal (un)certainty}

Article 1 ARNCP provides that the scope of this piece of legislation is not confined to a mere implementation of Directive 2014/60/EU. Accordingly, it establishes the authorities and proceedings for the restitution of cultural property by Poland both on its territory and abroad, as well as the authorities competent for restitution performed with respect to the cultural property of foreign countries and foreigners located in the territory of Poland. Hence the ARNCP also applies to other return or restitution regimes (e.g. the 1970 UNESCO Convention). Arguably, this extended broad scope creates a number of uncertainties.

In addition, Article 2(3) of the ARNCP defines "cultural property unlawfully removed from the territory of Poland", and in doing so it significantly goes beyond

31 P. Stec, op. cit., 139. 
a rather restrictive meaning of "unlawful removal from the territory of a Member State" under Directive 2014/60/EU. As already explained, Directive 2014/60/EU clearly states, in Article 2(2), that only objects removed from the territory of a Member State in breach of its rules on the protection of national treasures or in breach of Regulation No. 116/2009, or not returned at the end of a period of lawful temporary removal or any breach of another condition governing such temporary removal, are to be considered as "unlawfully removed"; while the catalogue contained in Article 2(3) ARNCP comprises a very long list of instances of unlawful removal.

According to this provision, the term "cultural property unlawfully removed from the territory of Poland" encompasses the following categories of cultural property: (a) "moved outside the territory of the Republic of Poland as a result of or in connection with the Second World War"; (b) "the export of which took place in breach of the regulations in force in the Republic of Poland regulating the export abroad of objects which are, within the meaning of those regulations, antiques, excavations or finds, artworks or objects of artistic, historical or cultural value, cultural goods, archival materials, museum collections or library materials, regardless of the time when the export took place"; (c) exported as a result of theft or misappropriation; (d) exported in breach of Regulation No. 116/2009; and (e) exported in contravention to the rules on lawful temporary removal. The ARNCP does not specify whether all these various categories are to be understood in light of the regime of return proceedings under Directive 2014/60/EU, or whether some of them may concern other instances of unlawful removal or subject to other restitution and return international law frameworks. It thus appears that the definition of "unlawful removal from the from the territory of Poland" under the ARNCP is also intended to address and concretize the breach of Poland's rules on the protection of national treasures within the meaning of Directive 2014/60/EU.

The most uncertain and troublesome category in this context is the first one, i.e. cultural property moved outside the territory of the Republic of Poland as a result of or in connection with the Second World War. ${ }^{32}$ It seems to suggest that any cultural property removed during this period is considered unlawfully exported. Such an assumption is not correct as it seems to cover removals lawfully carried out by persons or entities entitled to do so. It was observed that "[a]t the legal level this provision is equal to an irrebuttable legal presumption of bad faith on the part of anyone acquiring an object removed (even lawfully at the time of export) from Polish territory as a consequence, or in connection with, WWII. Any protection of the goods' owner, as a good faith purchaser, would be excluded." ${ }^{33}$ Moreover, the wording of Article 2(3)

\footnotetext{
32 Ibidem, 139-40.

33 Ibidem, 140.
} 
ARNCP is not clear whether the reference is made to the state territory within its 1939 or 1945 borders. Since Poland's boundaries differed significantly in these two periods, such an imprecise formulation could be the source of serious doubts and legal uncertainties. In particular, it may affect proceedings before a competent organ of another EU Member State considering a request submitted to the Polish authorities for the return of a cultural object under Directive 2014/60/EU.

These shortcomings in the Polish legislation, undoubtedly motivated by Poland's historical policy and its goals relating to the restitution of cultural war losses, can lead to negative and undesirable consequences. In other words, all this could mean that cultural goods saved and removed outside the conflict zone by Holocaust victims could fall into this category, thus negatively affecting the implementation of the 1998 Washington Conference Principles on Nazi-Confiscated Art ${ }^{34}$ and the 2009 Terezin Declaration on Holocaust Era Assets and Related Issues. ${ }^{35}$ This category could also include cultural property transported by Polish refugees from territories that were incorporated into the Soviet Union, or those goods that had been evacuated by German authorities and citizens from territories that were incorporated into Poland only after the end of the Second World War.

\section{"National cultural property" belonging to "public collections"}

Another problem in terms of legal certainty arising from the ARNCP's regime refers to the definition of public collections for purposes of restitution proceedings. As explained, Directive 93/7/EEC defined "public collections" as not only property defined as "public" under the legislation of a Member State, but also objects in "the inventories of ecclesiastical institutions". This solution, originally adopted upon the request of Greece, was subsequently modified during the works on Directive 2014/60/EU. According to Article 8(2), such collections mean "collections, defined as public in accordance with the legislation of a Member State, which are the property of that Member State, of a local or regional authority within that Member State or of an institution situated in the territory of that Member State, such institution being the property of, or significantly financed by, that Member State or local or regional authority." Although "objects belonging to inventories of ecclesiastical or other religious institutions" may not fall within this category, return proceedings that regard such objects shall be subject to the time-limits

34 Adopted 3 December 1998, https://www.state.gov/washington-conference-principles-onnazi-confiscated-art, 30.09.2021.

35 Adopted 30 June 2009, https://www.state.gov/prague-holocaust-era-assets-conference-terezindeclaration, 30.09.2021. 
applicable to proceedings concerning public collections, provided that they are subject to special protection arrangements under national law (Article 8(2)).

The Polish regulatory solution under the ARNCP goes well beyond the protective scope of Directive 2014/60/EU. Under the general regime of the APGM, "public collections" are defined as monuments owned by the state, local government units, or other organizational units belonging to the public finance sector. ${ }^{36}$ In accordance with the ARNCP, these monuments may not be permanently exported abroad, except in connection with the performance of a legal obligation to return a foreign national cultural property to another Member State. However, Article 2(6) of the ARNCP greatly expands the category of "public collections", which covers cultural property owned by the state; units of the public finance sector; and other entities using or disposing of public funds, or disposing of monuments or other cultural goods, maintained, directly or indirectly, with public funds. It also comprises cultural property of non-governmental organizations and entities conducting public benefit activities, performing public tasks in the field of culture, art, or the protection of cultural goods and national heritage, even if these are not maintained, directly or indirectly, using public funds.

Under Chapter 5 of the ARNCP the ownership of such national cultural property may not be acquired from a person not entitled to dispose of it, nor by prescription. An action for restitution of a national cultural property of the Republic of Poland belonging to public collections shall not be subject to prescription, whereas an action by a purchaser who in good faith purchased a national cultural asset of the Republic of Poland belonging to public collections from a person not entitled to dispose of it, to which the purchaser is entitled against that person and persons jointly and severally liable with him, shall be subject to prescription after ten years from the date of restitution of the national cultural property of the Republic of Poland to its owner. It is important to note that the provisions of Chapter 5 apply mutatis mutandis to national cultural property of the Republic of Poland belonging to churches and other religious groups, as well as to entities established by them.

Clearly, these solutions with respect to non-governmental organizations and other private (ecclesiastical or other religious) institutions may give rise serious doubts as to their compatibility with the provisions concerning the protection of property rights under EU law, the First Protocol to the European Convention on Human Rights, ${ }^{37}$ and Polish constitutional law. ${ }^{38}$

\footnotetext{
36 See Article 51(4)(3) and Article 56a(2).

37 Signed on 20 March 1952, entered into force on 18 May 1954, ETS No. 009.

38 See P. Stec, op. cit., 140-42; A. Frankiewicz-Bodynek, P. Stec, op. cit., 79-91.
} 


\section{CONCLUDING REMARKS}

There is no doubt that cultural heritage today constitutes a truly important element of the joint activities of the EU and its Member States. The emergence of the Single Market in 1993 was coupled with the adoption of solutions that would allow for the protection of national treasures and the protection of Member States' competences in the field of cultural heritage. In this sense, the protection of the integrity of their heritages and the mutual respect for the diversity of legal protection models are also important for the promotion of diversity within the EU. It is therefore not only about the diversity of cultures, traditions, languages, forms of cultural expression and practices in the EU, but also refers to mutual respect for constitutional traditions, which are also part of the common European cultural heritage.

Taking into account these goals and considerations, Member States should shape their national legal solutions transposing Directive 2014/60/EU in such a way as to ensure the effective implementation of these goals, including the certainty of trade in cultural goods. Moreover, the protection of the integrity of cultural heritage in the name of collective national interests must not conflict with the protection of fundamental rights. As the analysis conducted in this article has shown, the 2017 Polish Act on the Restitution of National Cultural Property (ARNCP) is burdened with a number of challenges related to the ambiguity of its regulations, their restrictive nature, and the predominance of the public interest over the rights and interests of other market participants. This may have negative consequences in terms of the certainty and ethics of the art market and the effectiveness of interstate and inter-institutional cooperation within the EU.

Dr ANDRZEJ JAKUBOWSKI

Rukovodilac projekta, Univerzitet Opole, Poljska

\section{KONCEPT KULTURNIH BLAGA PREMA PRAVU EU I POLJSKOM PRAVU KULTURNOG NASLEĐA}

\section{Rezime}

„Nacionalno blago“ jedan je od ključnih pojmova prava kulturnog nasleđa. Ono je od posebnog značaja za Evropsku uniju u kontekstu slobodnog kretanja robe na jedinstvenom tržištu i dozvoljenih izuzetaka ove slobode. Izuzeci se, u principu, odnose na one objekte „koji poseduju umetničku, istorijsku ili arheološku vrednost“, čije je očuvanje od vitalnog kulturnog interesa konkretne države članice. Stoga, nacionalna zakonska ograničenja pri uvozu i izvozu takvih objekata ne predstavljaju 
povredu ugovornih obaveza na snazi, sve dok takva ograničenja nisu proizvoljna ili ne pretpostavljaju prikrivena ograničenja u trgovini između država članica. Postavlja se, međutim, pitanje o praktičnom značenju ovog pojma, odnosno da li države članice imaju pravo da slobodno odrede šta predstavlja „nacionalno blago“. Ovaj članak nastoji da odgovori na postavljeno pitanje analizirajući kako je pojam nacionalnog blaga transponovan u poljski pravni sistem 2017. godine i koje su posledice ove regulatorne aktivnosti.

Ključne reči: trgovina umetničkim delima, izuzeci za umetnička dela, kulturno nasleđe, Evropska unija, Poljska

\section{Bibliography}

Biondi A., "The Merchant, the Thief \& the Citizen: The Circulation of Works of Art within the European Union", Common Market Law Review, Vol. 34, No. 5, Leiden, 1997.

Cheng J.M., “The Problem of National Treasure in International Law”, Oregon Review of International Law, Vol. 12, No. 1, Salem, 2010.

Cornu M., "Recasting Restitution: Interactions between the EU and International Law", Uniform Law Review, Vol. 20, No. 4, Rome, 2015.

Craufurd Smith, R., "Europe", The Oxford Handbook of International Cultural Heritage Law (Eds. Francesco Francioni, Ana Filipa Vrdoljak), Oxford, 2020.

Ferrazzi S., "EU National Treasures and the Quest for a Definition", Santander Art and Culture Law Review, Vol. 5, No. 2, Opole, 2019.

Frankiewicz-Bodynek A., Stec P., "Defining 'National Treasures' in the European Union. Is the Sky Really the Limit?", Santander Art and Culture Law Review, Vol. 5, No. 2, Opole, 2019.

Frigo M., "Cultural Property v. Cultural Heritage: A 'Battle of Concepts' in International Law?", International Review of the Red Cross, No. 854, Vol. 86, Cambridge, 2004.

Gagliani G., "Interpreting and Applying Article XX(f) of the Gatt 1994: 'National Treasures' in International Trade Law", Santander Art and Culture Law Review, Vol. 5, No. 2, Opole, 2019.

Graziadei M., Pasa B., “The Single European Market and Cultural Heritage: The Protection of National Treasures in Europe", Cultural Heritage in the European Union. A Critical Inquiry into Law and Policy (Eds. Andrzej Jakubowski, Kristin Hausler, Francesca Fiorentini, Boston-Leiden, 2019.

Jakubowski A., "Common Cultural Heritage, the European Union, and International Law", Cultural Heritage in the European Union. A Critical Inquiry into Law and Policy (Eds. Andrzej Jakubowski, Kristin Hausler, Francesca Fiorentini, Boston-Leiden, 2019.

Kyriakou T., “The Protection of National Treasures in the EU Single Market”, Cultural Governance and the European Union (Ed. Evangelia Psychogiopoulou), London, 2015.

Psychogiopoulou E., The Integration of Cultural Considerations in Eu Law and Policies, Boston-Leiden, 2008. 
Scott C., "Conceptions of a Shared, Common, or European Heritage in the Emerging Heritage Diplomacy of the European Union, 1973-92", Cultural Heritage in the European Union. A Critical Inquiry into Law and Policy (Eds. Andrzej Jakubowski, Kristin Hausler and Francesca Fiorentini), Boston-Leiden, 2019.

Shi J., Free Trade and Cultural Diversity in International Law, Oxford-Portland, 2013.

Stamatoudi, I.A., Cultural Property Law and Restitution: A Commentary to International Conventions and European Union Law, Cheltenham-Northampton, 2011.

Stec P., "The Lady or the Tiger? Legal Pitfalls of Implementing the Return of Cultural Goods Directive", Santander Art and Culture Law Review, Vol. 2, No. 2, Bydgoszcz, 2016.

Voon T., "National Treasures at the Intersection between Cultural Heritage and International Trade Law", The Oxford Handbook of International Cultural Heritage Law (Eds. Francesco Francioni, Ana Filipa Vrdoljak), Oxford, 2020.

Article history

Received: 07.10.2021.

Accepted: 24.10.2021.

ORIGINAL SCIENTIFIC PAPER 